\title{
RELIGIOUS IDENTIFICATION AND SOCIAL DISTANCE BETWEEN RELIGIOUS GROUPS IN YOGYAKARTA
}

\author{
Cahyo Pamungkas*
}

\begin{abstract}
ABSTRAK
Artikel ini menjelaskan bagaimana perubahan-perubahan politik, keagamaan, dan ekonomi di Yogyakarta berpengaruh terhadap proses pembentukan identitas agama dan penciptaaan jarak sosial antar kelompok umat beragama di daerah tersebut. Fenomena menguatnya identitas agama di daerah ini terjadi pada masa Perang Diponegoro (1825-1830) ketika isu agama digunakan dalam mobilisasi masa untuk melawan kekuasaan kolonial. Penyebaran agama Nasrani pada akhir abad ke19 telah menimbulkan ketegangan antara misionaris dengan sejumlah organisasi kemasyarakatan Islam, namun tidak berkembang menjadi konflik kekerasan. Walaupun kota Yogyakarta berkembang pesat sebagai pusat pemerintahan dan ekonomi, hubungan antar kelompok agama atau suku di daerah ini relatif harmonis. Namun, sejak tahun 1980-an, identitas agama kembali menguat baik di kalangan perkotaan maupun perdesaan seiring dengan proses modernisasi kehidupan masyarakat. Lembaga-lembaga dakwah kampus menjadi penggerak kehidupan keagamaan di perkotaan. Reformasi 1998 justru menandai bangkitnya gerakan-gerakan fundamentalisme keagamaan yang pada tingkatan tertentu berkontribusi pada penciptaan jarak sosial antar umat beragama.
\end{abstract}

Kata kunci: perubahan sosial, identitas agama dan suku, jarak sosial

\begin{abstract}
This paper explains how political, religious, and economic changes in Yogyakarta affect the formation of religious identity and social distance between different religious groups. The strengthening of religious identity in this area took place in the period of the Diponegoro War (18251830) when religious issues were used in the mobilization against the Dutch colonialist. Then, the spread of Christianity in Java at the end of $19^{\text {th }}$ led to several tensions between missionaries and several Islamic organizations, but never developed into communal violence. In 1930s, the relation between religious groups remain harmonious due to the development of tolerant culture and pluralism. During the 1980s, the use of religious identity grew both in urban and rural areas in line with social processes of modernization. Da'wat activities on Campus (Lembaga Dakwah Kampus) plays important roles in promoting religious life in urban areas. The 1998 political reform marked the rise of religious fundamentalist movements that to a certain degree contributes to social distance between religious groups.
\end{abstract}

Key words: social changes, religious identity, social distance

\footnotetext{
* Research Centre for Regional Resources (PSDR), the Indonesia Institute of Sciences (LIPI)
} 


\section{INTRODUCTION}

Yogyakarta is a home for many ethno-religious groups because it is the centre of provincial government, education and economic activities. Previous researches show that Yogyakarta has always been a relatively harmonious and peaceful city (Selosoemardjan, 1962:211-212; Sumartana et al., 1999:241). For example, at the beginning of the 1998 political reformation, unlike in many other cities in Indonesia, demonstrations by students and community groups were peaceful. It also appears that Yogyakarta has low levels of attitudes on contact avoidance between ethno-religious groups. Based on the Study on the relation between ethno religious groups of students in Yogyakarta, Interfidei reports that ethno religious groups have harmonious and peaceful contact in everyday life mainly at the grass-root level (Sumartana et al., 1999: 241). This study reveals a developed spirit in search for relation pattern between ethno religious groups in everyday life that enables them to stay together and respectful toward their differences. However, in the present day Yogyakarta, fundamentalist and radical Islamic groups have recently become active in the city (Fox, 2004:16-17; Umam, 2006:9-15). Religious identities become more salient compared to the period before 1998 political reform. Social distance between Muslims and Christians begins to appear in the daily lives. This paper attempts to address the question: how political, religious, and economic changes affect the increase of religious identification and social distance between Muslims and Christians in greater Yogyakarta.

\section{THEORETICAL FRAMEWORK}

Social changes is conceptually regarded as social transformation that consists of three elements: increasing complexity in a society, rising new social characteristics observable in certain period of history, and formation of policies that support the transformation (Abdullah, 2012). Cultural aspects are object of social changes as well as parts of infrastructure that support social transformation. Religion as a part of cultural aspect could be either supporting or resisting factor to social changes. It is a product, and reproduced in everyday life; its development is closely related to modernization. Religious values support changes from a society which adhered to magical values to one characterized by rational values (Abdullah 1994). They then eliminate cultural bond in societies that emphasize collectivism and are sources of inspiration in economic activities, as demonstrated by Calvinism in Western Europe and Shinto in Japan (Abdullah, 2012).

On the other side, modernity characterized by advance economic and political development creates competition between social groups, either actual or symbolic. Ethnic group conflict theory mentions that the stronger the competition between groups at individual as well as at contextual level, and the stronger the perceived threat, the more the mechanisms of social identification will be reinforced (Gijsberts et al., 2004). The process of religious identification is a process through which individuals obtain their self image from being members of a social group, with attached value and emotion significances (Tajfel, 1981). Social groups, including religious groups, are defined by not only similarities among members, but also a cognitive component, i.e., knowledge to belong to a group, an evaluative one that the notion of the group membership relates to value connotation, and the emotional component in the sense that cognitive and evaluative aspects relate to emotions (Tajfel, 1978).

Some theoretical propositions assert that, in most cases, social identification is likely to induce some exclusionary attitudes. Weber (1978) claims that certain groups employ their identities in an exclusionary manner to maintain and enhance their position in intergroup relations. Individuals who possess strong religious identification tend to support exclusionary attitudes. The extrinsic values of their religious convictions contribute to creating intergroup bias (Allport, 1966). Social distance is an example of exclusionary attitudes toward out-group members. It is an individual's attitude to avoid or reject members of out-groups as spouse in marriage, close friends, neighbours, colleague in employment, and residents in the city (Bogardus, 1925). Social distance can be perceived as latent conflict because it has reference to psychological aspects of conflict, such as hostility and stereotyping. As a latent conflict, social distance roots in prejudice, hostility, and ethnocentrism. The ethnocentrism is associated 
with a view that one's own group is the central of everything, and all others are measured with reference to it (Sumner, 1959).

\section{THE PRESENT DAY YOGYAKARTA}

Yogyakarta refers to greater Yogyakarta, which consists of the city of Yogyakarta and the adjacent regencies of Sleman and Bantul. In 2010, the total population is 2,393,240 (BPS DIY, 2011:181). Muslims make $90.72 \%$, Protestants and Catholics $3.23 \%$ and $5.75 \%$, while Hindus and Buddhists $0.17 \%$ and $0.10 \%$ of the total population. Compared with data from 1980, the percentage of Muslims decreased slightly, i.e., 2.54\% (BPS DIY, 1981:48). In the same period, the percentage of Protestants and Catholics increased slightly by $1.32 \%$ and $1.22 \%$ respectively. The religious composition of the population in greater Yogyakarta differs slightly from the provincial levels. At the provincial level, in 2010 Muslims are $91.95 \%$, Protestants $2.73 \%$, Catholics $4.79 \%$, Hindus $0.15 \%$, and Buddhists $0.10 \%$ of the total population.

Yogyakarta has an even greater variety of ethnic groups. The first official census of 1930 shows that the population of Yogyakarta was 143,909 which consisted of $88.38 \%$ Indonesians, $6.30 \%$ Chinese, $3.88 \%$ Europeans and $0.11 \%$ other Asians (Department van Landbouw, Nijverheid en Handel, 1931a:24). No information on the ethnic composition of the native population at the provincial level was included though it is predicted Javanese was the majority. The subsequent censuses from the nation's independence to $2000 \mathrm{did}$ not include ethnic categories. Only since the turn of the 20th century was the ethnic identity of inhabitants included in the census again. In 2010, the Javanese made up the majority $(96.54 \%)$ of Yogyakarta population, while the rest consisted of a great number of minorities that did not exceed 3.50\% (BPS, 2011b: 34). The 'main' ethnic minorities in the urban conglomerate were Sundanese, Malay, Chinese, Batak, Madurese, Minangkabau, Dayak, Papuan, Balinese, as well as people from Nusa Tenggara Timur and Lampung.

In all economic sectors, a variety of ethnic groups are represented. Only a few sectors are dominated by members of one or two ethnic groups. The restaurant sector is dominated by either Javanese, Minangkabau or Chinese. Security jobs are typically occupied by Javanese and people from East Nusatenggara. Food industry, more specifically milk and bakeries, inter-regional transportation and cell-phone and computer shops are often owned by the Chinese (Susanto, 2008:140). Home industries like handicraft and batik production are dominated by the Javanese, just like the street trade (Brata, 2008:9). Since 2000 , an increasing number of business activities are established along religious lines, such Islamic fashion, Islamic banking, halal food stores and restaurants. Quite a few real estate businessmen try to attract Muslim customers only. Like in other cities in Indonesia, businesses that use religious symbols flourish in the region of Yogyakarta. To a lesser extent, there are stores and real estate that only serve Christian communities.

Yogyakarta started to become a centre of education during the revolutionary period. In 1948, the first state university, Universitas Gadjah Mada (UGM), was founded on the premises of the court (kraton). In 1958, it moved to its present location in Sleman. Nowadays, there are 10 state and 120 private higher educational institutes in greater Yogyakarta. In 2009, the student population reached 246,793 in greater Yogyakarta; 74,707 studying at state universities and 172,086 at private ones (BPS DIY, 2011: 129, 159). About one fifth of them $(53,275$ persons) studied in Yogyakarta City, and the rest in Sleman and Bantul (BPS Kota Yogyakarta, 2011:48). Some students are member of religious organizations on campus, or ethnicbased organizations especially those coming from other regions.

\section{POLITICAL CHANGES}

The phenomenon of social distance in Yogyakarta is in line with social changes covering political, economic, and religious changes. Before the Dutch arrived in the Indonesian archipelago, the kings (susuhunan) of Mataram had absolute power over the territory stretching from Cirebon in West Java to Madura in East Java. After 1705, Mataram Kingdom started to shrink and the main parts of its territory fell into the Dutch control. Due to internal disputes and conflicts among the nobility, the Dutch had to intervene several times into the internal affairs of the kingdom. As for the compensation, the kings had to cede portions of their territories 
to the Dutch, i.e., Cirebon and Madura in 1705, and the North Coast of Java and Eastern Java in 1743 (Ricklefs, 1974:39; 2008:105). In 1755, once powerful Mataram Kingdom was finally divided into two principalities, Yogyakarta and Surakarta, each governed by the sultan and the susuhunan. The new sultan or susuhunan entered into a contract with the Dutch, and whenever the contract was renewed, their authority grew more restricted. For example, in 1785 the Sultan of Yogyakarta had to accept the presence of a Dutch Resident and Dutch troops to inhabit the newly built fort Vredeburg located near the palace (Suhatno, 2006:1-2; Marinhandono, 2008:16-17). Between 1755 and 1940, nine contracts between the ruling sultans and the Dutch were signed in this principality. As the consequence, the sultanate lost the right to appoint high officials, to have an army and to grant amnesty (Selosoemardjan, 1962:14-15; Kurniadi, 2009:194). As previously mentioned, at the beginning of the $19^{\text {th }}$ century, part of the principality was given over to another descendent of the Mataram dynasty, who took the title of paku alam.

After the proclamation of Indonesia's independence by Soekarno and Hatta in August 1945, the Sultan and the Paku Alam voluntarily took the side of the new republic. Out of gratitude, President Soekarno granted Yogyakarta a special territory status, while the position of governor and vice-governor were reserved for the sultan and the paku alam. Besides serving as a traditional ruler and the provincial governor, Sultan Hamengkubuwono IX was also Minister of Defence in several cabinets during the Soekarno regime from 1950 to 1953. During the Soeharto regime, the Sultan served as the Coordinating Minister of Economic Affairs-CMEA-between 1966 and 1967, and the vice-president between 1973 and 1978. After he passed away in 1989, the position of sultan was passed on to his eldest son, and Paku Alam VIII was appointed by the national government as the caretaker of Yogyakarta Governor. After Paku Alam VIII died in 1998, Sultan Hamengkubuwono $\mathrm{X}$, who later became the chairman of the political party Golkar at the provincial level, assumed the position of Yogyakarta governor. His automatic conferral to this position immediately became a point of debate in the provincial parliament and national government circles. However, this 'ascribed' rights was respected due to the people's pressure. Initially, the national government was reluctant to appoint Paku Alam IX, the son of Paku Alam VIII, as the vice-governor of Yogyakarta as there was no legal basis for it. In 2003, the position of vice-governor was resumed by the appointment of Paku Alam IX by the provincial parliament.

When the Indonesian people were given the right to vote, secular parties received the majority of votes both in the national elections and in Yogyakarta. In the first national election in 1955, the Indonesian Communist Party (Partai Komunis Indonesia, PKI) won $26 \%$ of the votes in Yogyakarta. The Indonesian Nationalist Party (Partai Nasional Indonesia, PNI) received $25 \%$, the Great Indonesia Movement (Gerakan Indonesia Raya, Gerinda) 14\%, the Islamic parties --Masyumi and Nahdlatul Ulama (NU)-- 19\% and $15 \%$ of the total votes, respectively (Luthfi and Soetarto, 2009:236). PKI attracted voters mostly from the nominal Muslims referred to as abangan, while PNI and Gerinda attracted voters from both the abangan and high ranking civil servants (priyayi). Masyumi and NU were particularly popular among the pious Muslims (santri) (van Bruinessen, 2002:141-144). Christian parties such as Partai Katolik and the Indonesian Christian Party (Partai Kristen Indonesia, Parkindo), earned only few votes. During the New Order period of of 1971-1998, only three political parties were allowed to run the election: Golkar, the political machine of the regime; the National Development Party (Partai Persatuan Pembangunan, PPP), a union of Islamic parties; and the Indonesian Democratic Party (Partai Demokrasi Indonesia, $P D I$ ), a union of Christian and nationalist parties. In all national elections held during the New Order, Golkar always won between $60 \%$ and $75 \%$ of the votes partially attributable to bribery and intimidation tactics that forced people to vote for the party (Suryadinata, 2002:32; Liddle and Mujani, 2007:834).

As described earlier, after the process of political reformation in 1998, several new political parties were founded. These parties were both nationalist (PDI-P and Partai Demokrat) and Islamic-based (PAN, PKS and PBB). In the 2004 local election in greater Yogyakarta, PDI-P won 
$32 \%$ of the seats, PAN $20 \%$, Golkar and PKS $14 \%$ each, while PKB and Partai Demokrat $11 \%$ and $7 \%$, respectively (BPS DIY, 2008:48). Christians from different ethnic groups and abangan supported the PDI-P, while santri voted for the Islamic parties (PPP, PAN, PKS and $\mathrm{PBB})$. A great number of santri and abangan also voted for nationalist parties, particularly Partai Demokrat and Golkar (Baswedan, 2004:672-675; Barton, 2010:133-135). One-fifth of the voters consisted of youth between the ages of seventeen and twenty-one. Several student organizations were affiliated with political parties and mobilized their members to vote for alumni who become member candidates for parliament. For example, the Indonesian Muslim Students Action Union (KAMMI) affiliated with PKS, while the Islamic University Students Association (HMI) sided with Golkar and Partai Demokrat (Machmudi, 2006:67; van Bruinessen, 2002:142). The Indonesian Christian Students Movement (GMKI) and the Indonesian National Students Movement (Gerakan Mahasiswa Nasional Indonesia, GMNI) worked together with PDI-P.

In short, religious orientations have influenced politics after the independence through confessional political parties. These religiously affiliated political parties stressed religious issues and regularly used religious language and symbols to attract voters. However, the degree of their political influence varies across periods. Before the New Order, pious Muslims voted for Masyumi and NU, nominal Muslims voted for PKI and PNI, while Christians voted for Parkindo or Partai Katholik. During the New Order, the government eliminated religious orientations from politics by restricting nationalist and Islamic parties. Nevertheless, religious orientation continued to influence political preference to a certain extent, in particular PPP that receives most votes from Muslims and PDI that found support from among Christians. After the fall of the New Order in 1998, votes were given to confessional parties such as PPP, PAN, PKS and PKB. Many pious Muslims living in rural areas traditionally supported for PPP and PKB, while those living in urban areas predominantly voted for PAN and PKS. However, the influence of religious orientation gradually declined in the 1999 to 2009 elections.

\section{ECONOMIC CHANGES}

Until the beginning of $20^{\text {th }}$ century, Yogyakarta was a court city, dependent on tax revenue and the labour of the peasant population. Peasants had to pay two-fifths of the rice harvests twice a year to the so-called apanage holders, i.e., members of the royal family and court officials, and onefifth of the harvest yield to village heads. Both apanage-holders and village heads were given by the sultan the rights to extract revenues. In turn, the apanage holders had to give two-fifths of their share to the sultan or paku alam (Wasino, 2005:32; Margana, 2007:97). During the British Interregnum (1811-1816), the Land Rent System was introduced in the greater part of Java, but not in Yogyakarta and Surakarta. This system forced the population to pay annual monetary taxes to the district collectors instead of imposing a variety of levies and duties (Carey, 1986:76-80). The Culture System or Cultuurstelsel, introduced by the Dutch in 1830 in several regions of Java, forced the population to cultivate products for export on onefifth of their land. This system however was not imposed in the principalities. Colonial interference in the agricultural system in Yogyakarta started at about the same time, when lands given as prebends to apanage holders were leased to private entrepreneurs for the cultivation of crops like coffee and indigo (Hugenholtz, 1986:142-143; Houben, 2002:66-67). The plantation holders obtained all the rights over these lands for a period of 20 years maximum (Selosoemardjan, 1962:33,262). ${ }^{1}$ Thus, the peasants did not enter into contracts with the plantation holders themselves unlike their peers elsewhere outside Yogyakarta (Suhartono, 1986: 178). Plantation holders consisted of (Indo-) Europeans; Chinese and other foreign Asians were not allowed to lease land. In 1918, the apanage system was abolished, and peasants in Yogyakarta were granted ownership of their lands (Selosoemardjan, 1962:34). Instead of taxes in kind or labour, they were subjected to a poll tax and a land tax, which amounted to $10 \%$ of the harvest yield (Stock quoted in White, 2004:4).

An Increase in the cultivation of commercial products by peasants resulted from the abolition of the apanage system. Parallel with this development, Yogyakarta changed from being primarily a court city into a predominantly commercial city. By 1920, 
Yogyakarta had developed into a relatively modern city with wide streets and Western-style buildings. On the border of the city, batik and other handicraft industries started to grow. In 1930, about 9\% of the population $(63,397$ persons) worked in batik making, silversmith and other home industries (Sitsen quoted in Haryono, 2009:104). The Javanese who owned and worked in these home industries and trades mostly came from villages inhabited by pious Muslims (Surjomihardjo, 2008:40). Among the owners of these businesses in Yogyakarta were some Chinese.

In those years, the economic activities undertaken by the Chinese had become more diversified. After the founding of the city of Yogyakarta, Chinese inhabitants worked as heads of gambling houses, artisans, painters and carpenters. At the end of $19^{\text {th }}$ century, they also worked as moneylenders, business brokers, tax farmers and rice traders (Bosma, 2007:73-94; Susanto, 2008:28-29). In the 1930s, many Chinese residents started hotel and restaurant businesses, as well as drugstores, pawnshops and home-industries, and produced various kinds of food, drinks, household equipment and furniture (Susanto, 2008:48-49). At that time, the Chinese also dominated batik manufacturing. In 1939, however, the Javanese started to dominate this home industry, after they founded the Union of Native Batik Companies (Persatuan Perusahaan Batik Bumiputera, $P P B B P$ ). During the Japanese occupation between 1942 and 1945, Chinese businesses were stymied because the new administration supported only Javanese businesses and organized them under the Progress of Indonesian Economy (Kemajuan Ekonomi Indonesia, KEI) scheme (Kwartanada, 2005:6-14).

Since the Japanese occupation, economic development deteriorated, and this trend continued during the independence struggle between 1945 and 1949. When the Dutch recognized Indonesian independence in 1949, many people in Yogyakarta had lost their jobs and lived in poverty. The Indonesian government had little money to jumpstart the economy or generate employment. Only batik production was subsidized by national government funds. Former aristocrat families ran batik and jewellery factories and profited from renting rooms to the increasing number of civil servants and migrants in the region. The Sultan himself tried to create employment opportunities by re-establishing the tobacco plantations, a sugar factory and a machine workshop that had been destroyed during the war. He also opened his palace to foreign tourists to increase the income (Dahles, 2001:62-64). Between 1955 and 1965, the national government launched several affirmative action programs for the development of native entrepreneurs, facilitating services to import goods and access to low interest credit. Many small and medium-sized industries and cooperatives were established, but they did not develop well due to inefficiency and the interference of political interests (Selosoemardjan, 1962:240). ${ }^{2}$

During the New Order era, tourism, manufacturing and the educational sector flourished. In the 1970s, Yogyakarta became the second top tourist destination after Bali. The city's historical monuments, including temples and palaces, began to attract an increasing number of domestic and foreign tourists. Tourism also influenced the local economy by driving the souvenir manufacture industry, the construction of new hotels and the development of other tourist services. In the same period, home industries such as weaving, batik, tobacco drying, printing and the production of wooden furniture grew (Kano, 1981:357). By 1971, Yogyakarta had been home to $22.5 \%$ of the state and private higher educational institutes in Indonesia. It was higher than the percentage of educational institutions in Jakarta $(12.5 \%)$. Newly founded universities and higher educational institutes attracted students from all over Indonesia, and local inhabitants as well as migrants opened businesses to cater students' need such as dormitories, restaurants and photocopy shops. From 1980, the construction industry, transportation industry and financial industry in the region developed significantly. In short, between 1969 and 1997, the economy of Yogyakarta diversified. Education, tourism, construction, transportation and manufacturing businesses flourished. After the economic crisis in 1997, the manufacturing industries collpsed, but trade and services increased. Many labourers that worked in manufacturing industries lost their jobs and found new employment in informal and service sectors (i.e. street trade and local transport). 
Javanese, Chinese and migrant populations contributed in different ways to, and profited in varying degrees from the economic development. Most large-scale enterprises belong to the Chinese, while the Javanese and migrants from outside the region owned small and medium-sized enterprises. After 1965, the New Order regime gave more opportunities to Chinese-owned businesses. It gave the Chinese community a significant hand in the construction and transportation sector. In the 1980 s, the community expanded into businesses in computer assembly, food processing and medicine. The economic crisis at the end of the New Order did not prevent the Chinese from setting up and eventually dominating the information technology industry in the region. Tensions between Chinese and native entrepreneurs was avoided at the urge of the local government officials, who encouraged the Chinese community to help native-owned businesses. One impediment to the growth of Chinese-owned business is that since 1975, the government has prevented Chinese from owning land and opening businesses in and around the palace and Kota Gede (Susanto, 2008:67-70). The role of migrants in the regional economy also increased after the economic crisis in 1997, when people from surrounding provinces came to work in some of the city's informal sectors. In 2008, about $29 \%$ of the street vendors in Yogyakarta and Sleman were migrants who came from Central Java (Brata, 2008:9).

\section{RELIGIOUS CHANGES}

Islam was introduced to the Indonesian archipelago during the $12^{\text {th }}$ and $13^{\text {th }}$ centuries. In the $14^{\text {th }}$ and $15^{\text {th }}$ centuries, the religion spread gradually along the northern coast of Java. Muslim traders and Islamic preachers from the Middle East, Persia and coastal India played an important role in the spread of Islam (Geertz, 1968: 9-13; de Jonge, 1997: 9495; Ricklefs, 2008: $3-8$ ). From the $17^{\text {th }}$ century on, Islam gained increasing followers in inland Java, particularly after the king of Mataram embraced Islam. Islamization occurred more rapidly in the last quarter of the $19^{\text {th }}$ century, when contacts with the Arab world increased after the opening of the Suez Canal.

According to Geertz (1960:5-6), Muslims in Java can be divided into two categories: santri, devout Muslims who adhere to purer Islamic traditions, and abangan, nominal Muslims who practice a syncretic religious system consisting of elements from Islam, Hinduism and traditional indigenous beliefs. Santri were originally found among traders in urban areas, and abangan mainly among peasants in rural areas (Ibid: 5-6). In contemporary society, however, santri can be found at all social levels, although they still dominate urban areas. Some authors have criticized Geertz's depiction of the duality of Java's Muslim population. According to de Jonge, the Indonesian Islamic community from the beginning has shown much more differentiation (1993).

At the beginning of the $20^{\text {th }}$ century, two Muslim organizations -Nahdlatul Ulama (NU) and Muhammadiyah- were established and had a great influence on the religious and societal emancipation of the population of the Indonesian archipelago. NU was very popular in the countryside. In Yogyakarta, the villages of Krapyak (Bantul) and Mlangi (Sleman) remain traditional centres of NUteachings. Both villages have several pesantren or Islamic boarding schools that attract many students every year, mainly from Central Java. Muhammadiyah, which tries to purify Islam from pre-Islamic influences and emphasizes prescribed ritual patterns, tends to flourish in urban areas (de Jonge, 1993:104). Muhammadiyah organizations supported Indonesian emancipation by founding hospitals, modern schools and orphanages (Fuad, 2002:133-135; van Bruinessen, 2004:5-11). In the course of time, after independence in particular, other Muslim organizations were founded, such as the Indonesian Islamic Da'wat Council (Dewan Dakwah Islamiyah Indonesia, DDII) and the Indonesian Association of Muslim Intellectuals (Ikatan Cendekiawan Muslim Indonesia, ICMI). DDII focuses on improving the level of $d a$ 'wat (making urge to virtuous deed) by opening study centres, publishing books and sending students to Islamic schools in Middle Eastern countries. ICMI organizes Muslim scholars to drive economic empowerment and lead communitybased education programs. In the last decade, Islamic communities (Jama'ah) that are more fundamentalist in orientation and are connected to a global network of Muslims have also flourished in urban areas (van Bruinessen, 2003:11-15). These 
organizations and congregations have a large number of followers among the student population in Yogyakarta.

Christianity was introduced in the Indonesian archipelago by the Europeans. Portuguese missionaries started to spread Catholicism in the Moluccas at the beginning of the $16^{\text {th }}$ century. The Dutch abrogated their proselytizing efforts after they replaced the Portuguese and introduced Protestantism in the same area. In Java, the Dutch only allowed Protestant and Catholic missionaries to spread their faiths from the beginning of the $19^{\text {th }}$ century, although there were already quite a number of converts in big cities. Protestantism started to take hold in Central Java in the middle of the $19^{\text {th }}$ century, and Catholicism at the end of the $19^{\text {th }}$ century. In Yogyakarta and the surrounding regions, Protestantism was introduced in 1859 , and Catholicism in $1865^{3}$ (Aritonang and Steenbrink, 2008:674). The intensive training of indigenous ministers in Central Java was a crucial factor in the initial spread of Protestantism between 1860 and 1870 . In the early $20^{\text {th }}$ century, Jesuit missionaries that had already founded schools and churches in Muntilan also settled in Yogyakarta, and made the city a centre of their missionary activities in Java. ${ }^{4}$ Christian converts were primarily made among the more syncretic abangan, and among the Chinese.

Unlike the case of Islam, Christianity spread more systematically through missionary orders and organizations. The colonial administration also allowed missionary organizations to start education and healthcare programs in local communities. In 1936, Protestant and Catholic missions controlled $35 \%$ of the village schools in Yogyakarta; most of their students in that year were nominal Muslims (Steenbrink, 2007:393). The schools and hospitals run by missionaries could not be matched by Islamic organizations in terms of numbers and qualities. Without doubt, their activities increased the number of Christian converts (Noer, 1973:2224). Between 1930 and 1932, the number of Catholics grew from 10,000 to more than 30,000 persons (van Klinken, 1996:97). In the same period, the number of Protestants increased from 2,208 to 3,148 (Sumartana, 1991:105). From the beginning, the colonial government was not always pleased with missionary activity, as it caused friction with the Muslim population, and even stimulated Muslim fanaticism (Hefner, 1993:99100; Aritonang, 2004:84-85).

After the independence, Indonesian priests and ministers gradually replaced their European colleagues. Between 1945 and 1949, some of the Protestant churches established by the Dutch split along ethnic lines, such as the Council of Chinese Christian Churches in Indonesia (Dewan Gereja-Gereja Kristen Tionghoa, DGKT) and the Protestant Evangelical Church in Timor (Gereja Masehi Injili di Timor, GMIT) (Aritonang and Steenbrink, 2008:826-831). At the same time, Protestant missionaries from Germany and the United States of America introduced new denominations, such as the Indonesia Evangelical Communion (Persekutuan Injili Indonesia, PII) and the Union of Pentecostal Churches in Indonesia (Persekutuan Gereja Pentakosta di Indonesia, $P G P I$ ), (ibid.: 867-868). In the early 1960s, the Catholic Church began to establish new dioceses and parishes in several cities in Indonesia. After the localization of Christian churches in the region, Indonesian churches continued to receive financial support from their fellow denominations in Europe and America from the 1960s on (Steenbrink, 2010:107-109).

After the 1965 coup d'état, the anti-communist Soeharto regime forced the population to choose one of the five approved monotheistic religions: Islam, Catholicism, Protestantism, Hinduism and Buddhism. This led tens of thousands abangan and Chinese inhabitants to convert to Christianity (Aritonang, 2004:412-414; Mujiburrahman, 2006:28-29). Among the abangan were many PKI members who tried to protect themselves through conversion, while many of the Chinese who were oriented towards the Chinese homeland opted to convert to Christianity for similar reasons. Converting to Islam was not as popular an option among the Chinese, because several Muslim groups cooperated with the Indonesian military in killing huge numbers of PKI members in 1965 and 1966 (Hefner, 1993:113-114; Bertrand, 2004:74-75). As a result, on the national level, the total number of Christians in Indonesia increased from $2.80 \%$ in 1933, to $7.50 \%$ in 1971 (Ricklefs, 1993:294). These conversions also led to an expansion of Christianity in Yogyakarta. Between 1974 and 2010, the number of Protestants and Catholics 
in Yogyakarta, increased from 81,342 to 114,794 people. This increase is attributable to the increase of Christian students from outside Yogyakarta, inter-religious marriage and natural growth. Also, in some rural areas many abangan converted to Christianity as missionaries provided them with basic services such as education and healthcare that government failed to provide (Willis, 1977:159).

\section{GROWING DISTANCE BETWEEN MUSLIMS AND CHRISTIANS}

During the colonial period, political conflicts often had ethno-religious dimensions. The most telling example in Java before 1900 is the Java War that took place between 1825 and 1830 which disrupted the entire society. Muslim Javanese considered this war as a symbol of their resistance against the Christian Dutch. The Chinese were also considered to be enemies, as they were positioned above the natives in the economic system of colonial Java (Carey, 1984:1-3). After the war ended, prejudicial relationships between the Dutch, the Javanese and the Chinese remained. On one side, Muslim Javanese referred to the Dutch as infidels to indicate their hatred (Noer, 1973:21). On the other side, the Dutch perceived Islam as a religion that had been used by Javanese to instigate rebellion (Arifianto, 2009:77). Since 1835, such bitter relationships were perpetuated by residential segregation in the city between the Dutch, the Chinese and the (pious) Muslims (Suryadinata, 1993:82). The Dutch lived in a European quarter, the Chinese inhabited China town and the (pious) Muslims stayed in Kampong Kauman. In 1910, this segregation was abolished because of the rapid population growth in the city. The prejudicial relationship however continued, especially between Dutch missionaries and Muslim preachers. The Dutch supported missionaries in encouraging the spread of Christianity, hoping that the Christian Javanese would support for the Dutch colonial state and consider the Dutch as their brothers. The Muslims leaders responded to missionary activities by consolidating their religious teachings and founding a number of modern religious organizations.

After the independence, mainly between 1950 and 1965, political conflicts with religious dimensions broke out in several provinces. The most visible conflict was the rebellion of armed groups that proclaimed the Indonesian Islamic state (Negara Islam Indonesia, NII) in the 1950s. In Yogyakarta, this rebellion found little or no support because Muslims in this region were strong supporters of the new Indonesian state proclaimed by Soekarno and Hatta. Another crucial political conflict was the failed coup d'etat by a group of armed forces that apparently conspired with leaders of the Indonesian Communist Party (PKI) in 1965. The Indonesian military used Muslim organizations to find support for their anti-communist campaign in Java. As Yogyakarta was a stronghold of PKI, tensions between members of communist organizations and Muslim organizations frequently erupted in the city (Harnoko et al., 1996:43-44). Many members of the PKI were imprisoned or executed by the Indonesian military in 1965-66. In 1966, the national government dissolved the PKI and forced all ethno-religious groups to live in harmony by imposing security measures.

In the first half period of the New Order, besides the extensive efforts of government to socialize public norms of harmony, the Sultan was said to have promoted tolerance towards religious and ethnic minorities in Yogyakarta. As a result, people from different religions and ethnicities lived together peacefully and engaged in a number of strategies to facilitate integration. The Chinese, for example, tried to create good relationships with the Muslim Javanese by speaking Javanese. Muslims and Christians exchanged food and visited each other during traditional ceremonies and religious parties (Kim, 1996:187-188). Inter-religious marriages, which was tolerated in the colonial time, continued to be in practice. Moreover, the tensions between Christian missionaries who worked in rural areas and Muslim organizations could be resolved in peaceful ways. In short, religious differences would not be a problem in daily live during these years. Interethnic Marriages further contributed to increasing cohesion.

During the second half period of the New Order regime, the distance between Muslims and Christians gradually grew wider. Between 1970 and 1990, the government marginalized Muslim organizations and appointed more Christians and nominal Muslims than pious Muslims in government. In those days, the old Islamic parties were banned and the new founded Islamic party, 
PPP, was restricted in its activities and was controlled by the government. As a result, Muslims underwent a process of going-back-to-Islam or santrinisasi because Islam was no longer politicized (Hefner, 1987:551). Distance between both groups increased, and harmonious relations between them gradually eroded as conservative Islamic beliefs spread in the region. For example, in 1980, the Council of Indonesian Ulema (Majelis Ulama Indonesia, MUI) issued a decree that prohibited Muslims from mixing their beliefs and practices with those of non-Muslims (Steenbrink, 1998:331). This decree discouraged Muslims from attending Christian ceremonies, including funerals (Mujiburrahman, 2006:284). These religious polarizations remained hidden as both groups avoided open conflict relationships. During this period, the government tended to suppress religious conflicts and promote public norms of religious harmony (Kim, 1996:178-188). Islamic movement also entered the university environment during this period. Several Islamic Da'wat Activities called Lembaga Dakwah Kampus (LDK), were founded on campus in the 1980s. They organized prayers and lectures on Islamic culture, and encouraged engagement with Islamic practices (Rahmat, 2003:23-24; Wahid et al., 2010:24).

In the 1990s, the Islamisation processes made inroads into government institutions, as the New Order regime persuaded santri (pious Muslim) population to give their political support. President Soeharto appointed more santris to the parliament and cabinets, and used the ICMI to channel his political interests. The government also began to allow female Muslim students to wear veils in public schools (van Bruinessen, 2002:134-135; Bertrand, 2004:83-84). Several Islamic preaching centres that spread conservative Islamic beliefs were founded in Yogyakarta, and the LDK became more popular among Muslim students in state universities. Although religious differences were becoming more apparent in Yogyakarta, effort was made to maintain religious harmony through the establishment of religious-based NGOs and other groups. Organizations like Interfaith Dialogue or interfidei (Dialog Antar Iman, DIAN) and Institute for Islamic and Social Studies (Lembaga Kajian Islam dan Sosial, LKIS) were created to address the state of inter-religious relations. When religious violence broke out between Muslims and Christians in Surabaya, Tasikmalaya and Situbondo in 1996, tensions were heightened in Yogyakarta as well. Religious leaders in Yogyakarta immediately implemented a program of interfaith dialogue, including discussions on sensitive topics like church burnings and missionary activities in Muslim communities. In 1997, as a follow up to the dialogue, they established the Forum of the Brotherhood of Faithful People (Forum Persaudaraan Umat Beriman, FPUB).

In the last twenty years, Muslims have become more aware of their religious identity than ever before, and as a result, the distance between Muslims and Christians even becomes wider. After the 1998 political reformation, Islamic Brotherhood Forum (Forum Ukhuwah lslamiyah, FUI) was founded by Muslims in Yogyakarta to coordinate local Islamic organizations. Apart from the coordination of da'wat activities, the FUI also tried to prevent Muslim pupils from going to Christian schools, and campaigned against pornography and drug use (Subhan, 2007:110-115). Muslim organizations knew how to prevent the activities of Christian missionaries in abangan communities. For example, they founded mosques and Islamic boarding schools in areas close to where Christian missionaries worked. In state universities, new Muslim groups affiliated with international organizations like Ikhwanul Muslimin, Hizbut Tahrir and Salafi organizations were popular among students, as they were facilitated and supported by the LDK. A large number of students joined these groups because the older Islamic student organizations (HMI, IMM and PMII) were perceived as only being concerned with seeking access to power (Machmudi, 2006:112). In daily life, they tend to create distance between Christians and Muslims outside of their groups by wearing specific Muslim dress, living in exclusive houses and avoiding interaction.

Besides the growing distance, some militant Muslim organizations were founded in Yogyakarta in the year 2000, an effect of the political reformation. These groups were the Jihad Force (Laskar Jihad) and the Indonesian Mujahiddin Assembly (Majelis Mujahiddin Indonesia, $M M I)$. Unlike other Muslim organizations, these 
groups sent thousands of militants to fight against Christians in Ambon and Poso between 2000 and 2002. Also, both groups demanded the implementation of Islamic law in Indonesia (Hasan, 2002:145-146). After the religious conflict in both cities ended in 2002, the Laskar Jihad was dissolved by its leader, while the MMI continues to exist but is not very active. Another militant group based in Jakarta, the Islam Defenders Front (Front Pembela Islam, FPI) opened a branch in Yogyakarta a few years after the decline of the Laskar Jihad and the MMI in Yogyakarta. This group is known for its anti-vice raids against bars, casinos and gambling businesses. In 2012, some members of Laskar Jihad even attacked LKIS office, while a discussion with an American liberal feminist was going on. Consequently, this group disturbs the harmonious relationship between Muslims and Christians in this region.

Christians also acknowledge the growth of some fundamentalist oriented groups like charismatic denominations that are increasingly exclusive. These groups reportedly adopted the same techniques used by fundamentalist Muslims to promote their beliefs in urban areas (van Bruinessen, 2003:17-19). Despite an establishment of a charismatic Christian denomination branch in Yogyakarta in 1980, there is a slow increase in its membership after the 1998political reformation. In 2004, its church in Yogyakarta claimed to have around 2,500 members (Koning, 2011:26). Many Chinese professionals in particular converted to charismatic Christianity, as they feel threatened by an increase of fundamentalist Muslims. With the increasing popularity of charismatic Christianity, Muslims regularly force those churches to close, sometimes because of the somewhat shallow reproach that their services are too noisy (Koning and Dahles, 2009:14-27). Although growing in number, charismatic churches are nevertheless relatively few in number and small in size compared with mainstream Christian denominations like the Javanese Christian Church (Gereja Kristen Jawa, $G K J$ ). Nowadays, some Christians feel themselves obliged to display their religious identity in daily life, e.g. by wearing religious symbols or praying in public, in response to growing Islamisation. In social media forums, they have expressed their critical opinions about violence conducted by
Muslim militias.

In recent years, ethnic and religious identities have become more salient among the student population. Before 1999, students from different ethno-religious groups maintained tolerant relations with each other (Sumartana et al., 1999:241). Recently, however, students from different ethnic and religious groups tend to avoid each other, which is not always that easy, as many of them take courses together and live together in private dormitories. As a matter of fact, many regional governments outside Java provide dormitories in Yogyakarta for students from their areas, although less than needed to house all the students from these regions (Mas'oed et al., 2001:126). Some regional dormitories have become so exclusive that people from other ethnic groups are afraid to visit them. According to Zudianto (2008:82), dorms have become places of people from one culture, instead of places of cultural interaction between ethnic groups. The wish to live among 'equals' is most prominent among fundamentalist Muslims and Chinese. Fundamentalist Muslim students prefer to live together in separate houses or dormitories to preserve their religious beliefs and traditions, while Chinese students prefer to do the same primarily for reasons of security.

\section{CONCLUSION}

The relation between religious groups in Yogyakarta before the Diponegoro war was solid. The political conflict between colonial administration and local people was often perceived as a religious conflict. Rapid economic development led to several tensions between local people and Chinese, but religious tensions and identification were relatively hidden. After the new order government came to power, religious identification started developing. Tensions between Muslims and Christians in Yogyakarta are a derivation of national policies that became a struggle of Muslim groups against national government. The modernization via education since 1980s contributed to the development of Islamic fanaticism in campuses. Islamic fundamentalism gives more spaces to the creation of social distance mainly contact avoidance, as well as exclusionism in living places.

After the 1998 political reform, religious orientations continues to influence politics, but 
decreasing compared to the previous periods. Unlike Abdullah (1994) who proposes that religious values are sources of inspiration for modernity through modern economic and cultural developments, this study demonstrates that modernity through education and democratic political system produce and reproduce religious identification. The strong religious identification followed by religious fanaticism, perceived threat, distrust against religious out-groups resulted only into prejudice and social distance between religious groups. The theoretical implication of this research is that studies on religious tensions and conflict cannot be separated from social and historical context, mainly relation of domination between religious groups.

\section{References}

Abdullah, I. (2012). 'Tantangan pembangunan Ekonomi Dan Transformasi Sosial: Suatu Pendekatan Budaya'. Humaniora, 14 (3), 260-270.

Abdullah, I. (1994). The Muslim businessmen of Jatinom: religious reform and economic modernization in a central Javanese town. Universiteit van Amsterdam.

Allport, G.W. (1966). 'The religious context of prejudice'. Journal for the Scientific Study of Religion, 5 (3), 447- 457.

Arifianto, A. R. (2009). 'Explaining the cause of Muslim-Christian conflicts in Indonesia: Tracing the origins of Kristenisasi and Islamisas'. Islam and Christian-Muslim Relations, 20 (1), 73-89.

Aritonang, J. S., \& Steenbrink, K. (2008). A history of Christianity in Indonesia. Leiden and Boston: Brill.

Aritonang, J. S. (2004). Sejarah perjumpaan Kristen dan Islam di Indonesia. Jakarta: BPK Gunung Mulia.

Badan Pusat Statistik(BPS). (2011b). Kewarganegaraan, suku bangsa, agama, dan bahasa sehari-hari penduduk Indonesia: Hasil sensus penduduk 2010. Jakarta: BPS.

Badan Pusat Statistik Daerah Istimewa Yogyakarta (BPS DIY). (1981). Daerah Istimewa Yogyakarta dalam angka 1980. Yogyakarta: BPS DIY.

Badan Pusat Statistik Daerah Istimewa Yogyakarta (BPS DIY). (2008). Daerah Istimewa Yogyakarta dalam angka 2007. Yogyakarta: BPS DIY.

Badan Pusat Statistik Daerah Istimewa Yogyakarta (BPS DIY). (2011). Daerah Istimewa Yogyakarta dalam angka 2010. Yogyakarta: BPS DIY.

Badan Pusat Statistik Kota Yogyakarta (BPS Kota Yogyakarta). (2011). Kota Yogyakarta dalam angka 2010. Yogyakarta: BPS Kota Yogyakarta.

Barton, G. (2010). Indonesia. In: B. Rubin (Ed.), Guide to Islamist Movements. New York: M.E. Sharpe, Inc.

Baswedan, A. R. (2004). Political Islam in Indonesia: Present and future trajectory. Asian Survey, 44 (5), 669-690.

Bertrand, J. (2004). Nationalism and ethnic conflict in Indonesia. Cambridge: Cambridge University Press.

Bogardus, E.S. (1925a). Social distance and its origin. Journal of Applied Sociology, 9, 216-226.

Bosma, U. (2007). Sugar and dynasty in Yogyakarta. In: U. Bosma, J. Giusti-Cordero, \& G. R. Knight (Eds.), Sugarlandia revisited: Sugar and colonialism in Asia and the Americas, 1800 to 1940 (pp. 73-94). New York: Berghahn Books.

Brata, A. G. (2008). Vulnerability of urban informal sector: Street vendors in Yogyakarta, Indonesia (Paper in Munich Personal RePEc Archive (MPRA) No. 12541). Retrieved August 16, 2010 from http://mpra.ub.uni-muenchen. de/12541/1/MPRA_paper_12541.pdf.

Carey, P. (1984). Changing Javanese perceptions of the Chinese communities in Central Java, 17551825. Indonesia, 37, 1-47.

Carey, P. (1986). Waiting for the 'just king': The agrarian world of South-Central Java from Giyanti (1755) to the Java War (1825-1830). Modern Asian Studies, 20, 59-137.

Dahles, H. (2001). Tourism, heritage and national culture in java: Dilemmas of a local community. Leiden: IIAS.

De Jonge, H. (1993). Western and Indonesian views on the abangan-santri division in Javanese society: the reception of Geertz's 'the religion of Java. In: H. Driessen (Ed.), The politics of ethnographic reading and writing, confrontations of Western and indigenous views (pp.). Saarbrucken, Germany: Verlag breitenbach publisher.

De Jonge, H. (1997). Dutch colonial policy pertaining to Hadhrami immigrants. In: U. Freitag \& W.G. Clerence-Smith (Eds.), Hadhrami traders, school and statesman in Indian Ocean 1750s-1960s (pp. 94-111). Leiden, New York, Koln: Brill.

De Jonge, H., \& Nooteboom, G. (2006). Why the Madurese? Ethnic conflicts in West and East Kalimantan compared. Asian Journal for 
Social Studies (AJSS), 34 (3), 456-474.

Department van Landbouw, Nijverheid en Handel. (1931a). Volstelling 1930. Voorloopige Uitkomsten le Gedeelte Java and Madoera. Preliminary results of the census 1930 in the Netherlands Indie part I Java and Madura. Batavia: Landsdrukkerij.

Fox, J. J. (2004, April). Currents in contemporary Islam in Indonesia (Paper presented at Harvard Asia Vision 21, Cambridge, Mass.). Retrieved November 10, 2010 from https://digitalcollections.anu.edu.au/ bitstream/1885/42039/2/Islam_in_Indonesia2. pdf.

Fuad, M. (2002). Civil society in Indonesia: The potential and limits of Muhammadiyah. SOJOURN, 17 (2), 133-63.

Geertz, C. (1960). The religion of Java. Glencoe: Free Press.

Geertz, C. (1968). Islam observed: Religious development in Morocco and Indonesia. New Haven: Yale University Press.

Gijsberts, M., Hagendoorn, L., \& Scheepers, P. (Eds.). (2004). Nationalism and exclusion of migrants: Cross national comparisons. Burlington, USA: ASHAGATE.

Hasan, N. (2002). Faith and politics: The rise of the Laskar Jihad in the era of transition in Indonesia. Indonesia, 73, 145-169.

Harnoko, D., Fakkih, M., \& Darban, A. (1996). Kebangkitan Orde Baru di Yogyakarta. Yogyakarta: Yayasan Tunas Bangsa dan Balai Kajian Sejarah dan Nilai Tradisional Departemen Pendidikan dan Kebudayaan.

Haryono, A. (2009). Bersahaja sekaligus perkasa: Perempuan desa dalam industri rakyat Yogyakarta 1830an-1930an. Historia Vitae, 23 (1). Retrieved April 10, 2012 from http:// www.usd.ac.id/lembaga/lppm/f113/Jurnal\%20 Historia\%20Vitae/vol23nol april2009/ BER S A H A J A \% 20 SEK A L I G U S \% 20 PERKASA\%20anton\%20haryono.pdf.

Hefner, R. W. (1987). Islamizing Java? Religion and politics in Rural East. The Journal of Asian Studies, 46 (3), 533-554.

Hefner, R. W. (1993). Of faith and commitment: Christian conversion in Muslim Java. In: R. Hefner (Ed.), Conversion to Christianity: Historical and anthropological perspectives on a great transformation (pp. 99-125). Berkeley \& Los Angeles: University of California Press.

Houben, V. J. H. (2002). Keraton dan kompeni: Surakarta dan Yogyakarta1830-1870 (E. Setyawati, Trans \& I. Risdiyanto, Ed.).
Yogyakarta: Bentang Budaya.

Hugenholtz, W. R. (1986). Taxes and society: Regional differences in Central Java around 1830. In S. Kartodirdjo (Ed.), Papers of the fourth Indonesian-Dutch history conference Yogyakarta 24-29 July 1983 volume one agrarian history (pp. 142-173). Yogyakarta: Gadjah Mada University Press.

Kano, H. (1981). 'Employment structure and labor migration in rural Central Java: A preliminary observation'. Development Economics, 4, 348-366.

Kim, Hyung-Jun Kim (1996). Reformist Muslim in a Yogyakarta village: the Islamic Transformation of Contemporary Socio-Religious Life. PhD thesis of Research School of Asian Pacific Studies, Australia National University.

Koning, J. (2011). 'Business, belief, and belonging: Small business owners and conversion to Charismatic Christianity'. In M. Dieleman, J. Koning, \& P. Post (Eds.), Chinese Indonesians and regime change (pp. 23-46). Leiden: Brill.

Koning, J., \& Dahles, H. (2009). Spiritual power: Ethnic Chinese managers and the rise of Charismatic Christianity in Southeast Asia. The Copenhagen Journal of Asian Studies, 27 (1), 5-37.

Kurniadi, B. D. (2009). Yogyakarta in decentralized Indonesia: Integrating traditional institution in democratic transitions. Jurnal Ilmu Sosial dan Politik, 13 (2), 190-203.

Kwartanada, D. (2005). "Kemadjoean Ekonomi Indonesia” (1941-1949): Rise and fall of a pribumi-Muslim economic organization from Yogyakarta (Paper presented at the international workshop on the economic aspect of decolonization in Indonesia, Leiden).

Liddle, R. W., \& Mujani, S. (2007). Leadership, party, and religion: Explaining voting behavior in Indonesia. Comparative Political Studies, 40 (7), 832-857.

Luthfi, A. N., \& Soetarto, E. (2009). Keistimewaan Yogyakarta: Yang diingat dan dilupakan. Yogyakarta: Sekolah Tinggi Pertanahan Nasional.

Machmudi, Y. (2006). Islamising Indonesia: The rise of Jemaah Tarbiyah and the Prosperous Justice Party (PKS) (Doctoral thesis, Australian National University, 2006).

Margana, S. (2007). Hybridity, colonial capitalism and indigenous resistance: The case of the Paku Alam in Central Java. In: U. Bosma, J. GiustiCordero, \& G. R. Knight (Eds.), Sugarlandia revisited: Sugar and colonialism in Asia and 
the Americas, 1800 to 1940 (pp. 95-112). New York: Berghahn Books.

Marihandono, D., \& Juwono, H (2008). Sultan Hamengkubuwono II: Pembela tradisi dan kekuasaan Jawa. Yogyakarta: Banjar Aji.

Mas'oed, M., Panggabean, S. R., \& and Azca, M. N. (2001). Social resources for civility and participation: The case of Yogyakarta, Indonesia. In R. W. Hefner (Ed.), The politics of multiculturalism: Pluralism and citizenship in Malaysia, Singapore, and Indonesia (pp. 119-140). Honolulu: University of Hawai'i Press.

Mujiburrahman. (2006). Feeling threatened: MuslimChristian relations in Indonesia's New Order. Leiden: ISIM, Amsterdam: Amsterdam University Press.

Noer, D. (1973). The modernist Muslim movement in Indonesia 1900-1942. Singapore: Oxford University Press.

Rahmat, M. I. (2003). Ideologi politik PKS: dari kampus ke gedung. Yogyakarta: LKIS.

Ricklefs, M. C. (1974). Jogjakarta unders Sultan Mangkubumi, 1749 - 1792: A history of the division of Java. London and New York: Oxford University Press.

Ricklefs, M. C. (1993). A history of modern Indonesia since C. 1300 ( $2^{\text {nd }}$ ed.). Stanford, California: Stanford University Press.

Ricklefs, M. C. (2008). A history of modern Indonesia since C. 1200 (4 $4^{\text {th }}$ ed.). Basingstoke: Palgrave Macmillan.

Selosoemardjan (1962). Social changes in Yogyakarta. Ithaca, New York: Cornel University Press.

Steenbrink, K. (1998). Muslim-Christian relations in the pancasila state of Indonesia. The Muslim World, 88 (3-4), 320-352.

Steenbrink, K. (2007). Catholics in Indonesia, 18081942: A documented history. Vol. 2 the spectacular growth of a self-confident minority. Leiden: KITLV Press.

Steenbrink, K. (2010). The power of money: Development aid and through Christian churces in modern Indonesia, 1965-1980. In S. Schroter (Ed.), Christianity in Indonesia: perspective power (pp. 105-136). New BrunswiclandondonTransactiorPublisher.

Subhan, I. (2007). Hiruk pikuk wacana pluralisme di Yogya, city of tolerance. Yogyakarta: Kanisius \& Impulse.

Suhatno. (2006). Yogyakarta dalam lintasan sejarah (Paper presented at a seminar on the history of Yogyakarta by the Yogyakarta Institute for Historical and Traditional Values). Retrieved
April 20, 2013 from http://www.javanologi. info/main/themes/images/pdf/SuhatnoLawatan_06.pdf.

Suhartono. (1986). The impact of sugar industry on rural life, Klaten, 1850-1900. In S. Kartodirdjo (Ed.), Papers of the fourth Indonesian-Dutch history conference Yogyakarta 24-29 July 1983 volume one agrarian history (pp. 174-195). Yogyakarta: Gadjah Mada University Press.

Sumartana, Th., Faruk, Lay, C., Laksono, P. M., \& Soetrisno, L. (1999). Pengalaman kesaksian dan refleksi kehidupan mahasiswa di Yogyakarta. Yogyakarta: Interfidei.

Sumartana, Th. (1991). Mission at the Crossroads: Indigenous churches, Europeans missionaries, Islamic association and socio-cultural change in Java 1812-1936. (Doctoral dissertation, Vreij University of Amsterdam, 1991).

Sumner, W.G. (1959). Folkways, a study of the sociological importance of usages, manners, customs, mores, and morals. New York: The New American Library.

Susanto, A. A. (2008). Under the umbrella of the sultan, accommodation of the Chinese in Yogyakarta during Indonesia's New Order (Doctoral dissertation, Radboud University of Nijmegen, 2008).

Surjomihardjo, A. (2008). Kota Yogyakarta tempo doeloe: Sejarah sosial 1880-1930. Yogyakarta: Komunitas Bambu.

Suryadinata, L. (1993). The State and Chinese Minority in Indonesia. Chinese Adaptation and Diversity: Essays on Society and Literature inIndonesia, Malaysiaand Singapore,77-99.

Suryadinata, L. (2002). Elections and politics in Indonesia. Singapore: Singapore University Press.

Tajfel, H. (1978). Social categorization, social identity and social comparison. In: H. Tajfel (Ed.), Differentiation between social groups: Studies in the social psychology of intergroup relations (pp. 61-76). London, New York, San Francisco: European Association of Experimental Social Psychology and Academic Press.

Tajfel, H. (1981). Human groups and social categories, studies in social psychology. Cambridge: Cambridge University Press.

Umam, S. (2006). Radical Muslims in Indonesia: The case of Ja'far Umar Thalib and the Laskar Jihad. Explorations: a graduate student journalofSoutheastAsianStudies, 6(1), 1-26.

Van Bruinessen, M. (2002). Genealogies of Islamic radicalism in post-Suharto Indonesia. South East Asia Research, 10 (2), 117-154. 
Van Bruinessen, M. (2003, August). Post-Suharto Muslim engagements with civil society and democracy (Paper presented at the third international conference and workshop 'Indonesia in transition', Jakarta). Retrieved April 20, 2013 from http://igitur-archive. library.uu.nl/let/2007-0312-083801/ bruinessen_04_postsoehartomuslim.pdf.

Van Bruinessen, M. (2004, May). Traditionalist' and 'Islamist'pesantren in contemporary Indonesia (Paper presented at the The international institute for the study of Islam and modern world (ISIM) workshop on 'The Madrasah in Asia'). Retrieved April 20, 2013 from http:// eprints.umm.ac.id/1107/.

Van Klinken, G. (1996). Migrant moralities: Christians and nationalist politics in emerging Indonesia, a biographical approach (Doctoral dissertation, Griffith University, Brisbane).

Wahid, A. (Ed.). (2010). Ilusi negara Islam: Ekspansi gerakan Islam transnasional di Indonesia. Jakarta: Maarif Institute, Wahid Institute, dan LibForAll Foundation.

Wasino. (2005). Tanah, desa, dan penguasa: Sejarah pemilikan dan penguasaan tanah di pedesaan Jawa. Semarang: UNNES Press.

Weber, M. (1978). Economy and society: An outline of interpretive sociology $(\mathrm{G}$. Roth \& C. Wittich,
Ed.). Berkeley: University of California.

White, B. N. F. (2004). Towards a social history of economic crises: Yogyakarta in the 1930s, 1960s and 1990s. In: H. Samuel \& H. Schulte Nordholt (Eds.), Indonesia in transition: Rethinking civil society, region and crisis (pp. 195-220). Yogyakarta: Pustaka Pelajar.

Willis, A. T. (1977). Indonesian revival why two million came to Christ. South Pasadena: William Carey Library.

Zudianto, H. (2008). Kekuasaan sebagai waqaf politik. Yogyakarta: Kanisius.

\section{(Endnotes)}

1 Although the apanage holders had leased out their prebends since 1830 , the colonial government only legally allowed the leasing system in Yogyakarta and Surakarta as of 1857. The maximum duration of the lease was extended to 30 years in 1918 (Selosoemardjan, 1962:262-263).

2 At the provincial level, the economy of Yogyakarta therefore was dependent on agriculture, mainly rice production. Peasants also cultivated sugar cane, maize, cassava, peanuts and soybeans (Selosoemardjan, 1962:240).

3 However, this religion was introduced to Yogyakarta people through the court photographer, Kassian Chepas (Aritonang and Steenbrink, 2008:673)

4 In Yogyakarta, few Javanese converted to Christianity. The religion is popular among individuals from minority ethnic groups such as the Ambonese, Papuans, Timorese, Torajanese and Manadonese. 